\title{
OPTIMALISASI PENGGUNAAN METODE EKSPERIMEN DALAM PEMBELAJARAN IPA UNTUK MENINGKATKAN PRESTASI BELAJAR SISWA
}

\author{
Ni Wayan Rati 1,*, Dewa Ayu Karmila Dewi ${ }^{2}$ \\ 1 Jurusan Pendidikan Guru Sekolah Dasar. Universitas Pendidikan Ganesha, Indonesia \\ 2 Jurusan Pendidikan Guru Sekolah Dasar. Universitas Pendidikan Ganesha, Indonesia
}

\begin{abstract}
Abstrak
Penelitian ini bertujuan untuk mengetahui apakah dengan mengoptimalkan penggunaan metode eksperimen dalam pembelajaran IPA pada siswa kelas IV SD No. 3 Petak, Kecamatan Gianyar, Kabupaten Gianyar Tahun Pelajaran 2010/2011, prestasi belajar dapat ditingkatkan.Penelitian ini adalah penelitian tindakan kelas melalui tahapan (1) Perencanaan, (2) Pelaksanaan, (3) Observasi, (4) Refleksi, yang dilaksanakan dalam dua siklus.Subyek penelitiannya adalah siswa kelas IV SD Negeri 3 Petak Tahun Pelajaran 2010/2011, sebanyak 22 orang. Pengumpulan data dalam penelitian ini menggunakan metode observasi dan test evaluasi. Data yang diperoleh dianalisis dengan menggunakan metode analisis deskriptif. Hasil penelitian yang telah dilakukan menunjukkan bahwa (1) prestasi belajar siswa menunjukkan 5,8 (58\%) masih dibawah penguasaan kompetensi minimal dan pada siklus II $70 \%$ sudah ada peningkatan dari hasil yang telah diperoleh dari siklus I ke siklus II sudah mencapai target maksimal.
\end{abstract}

\author{
Keywords: \\ Prestasi Belajar, Metode \\ Eksperimen
}

\section{Pendahuluan}

Banyak masalah yang dihadapi dalam dunia pendidikan saat ini baik dalam bidang kualifikasi akademik guru samapai pada prestasi yang kurang mengembirakan. Pada beberapa mata pelajaran seperti IPA, menurut laporan UNICEF, Indonesia menduduki rengking ke 135 dari 137 negara di bawah Vietnam. Hal ini merupakan informasi yang sangat memilukan pada pendidikan kita.Sebenarnya pemerintah sudah melakukan berbagai upaya dalam perbaikan pendidikan guna meningkatkan mutu pendidikan kita.Tetapi hasilnya tetap sangat memprihatinkan pada guru yang sudah mendapatkan pelatihan kurang mau dan kurang mampu dalam mengaplikasikan hasil pelatihan yang diperoleh dalam pembelajaran. Guru sebagai ujung tombak pelaksanaan pendidikan pada dunia persekolahan paling bertanggung jawab dalam melakukan perbaikan layanan pembelajaran. Layanan pembelajaran perlu dioptimalkan dengan melalui penerapan metode pembelajaran yang baik dan benar. Pembelajaran yang diberikan oleh guru dengan memberikan pengalaman siswa untuk melakukan akan memberikan dampak besar dalam pemahaman dan penguasaan kompetensi yang dituntut. Pembelajaran IPA sangat memungkinkan memberikan pengalaman langsung kepada siswa, karena karakteristik IPA adalah mempelajari hal-hal yang bersifat nyata. Untuk itu guru dapat mengemas pembelajaran IPA dengan metode secara optimal memberikan pengalaman kepada siswa.Salah satu metode tersebut adalah metode eksperimen. Dengan menerapkan metode eksperimen dengan tepat dan optimal, siswa akan dapat belajar dengan baik sehingga prestasi belajarnya akan dapat ditingkatkan.

Pada mata pelajaran IPA sering menjadi masalah baik mengganti hasil belajar yang kurang maupun keterlibatan belajar siswa yang belum optimal. Di kelas IV SD No 3 Petak, Gianyar banyak siswanya 22 orang, secara umum prestasi belajarnya pada masa pelajaran IPA belum memadai. Rata-rata nilai mata pelajaran IPA 5,8 masih di bawah penguasaan kompetensi minimal, sedangkan target minimal adalah 7,0. Hal ini yang mengharuskan guru untuk mengadakan program perbaikan pembelajaran, agar hasil belajar siswa dapat ditingkatkan, maka pengelolaan pembelajaran perlu dioptimalkan melalui penerapan metode eksperimen. Perbaikan pembelajaran dilakukan berdasarkan atas permasalahan yang

\footnotetext{
* Corresponding author.

E-mail Addresses niwayan.rati@undiksha.ac.id (Ni Wayan Rati), karmiladewi@gmail.com (Dewa Ayu Karmila Dewi),
} 
muncul di kelas. Dari hasil refleksi yang dilakukan teridentifikasi masalah pembelajaran khususnya yang terjadi.

Masalah-masalah yang ditemukan setelah melakukan pengamatan di SDNo. 3 Petak adalah sebagai berikut: 1) Hasil belajar siswa pada mata pelajaran IPA masih kurang; 2) Keterlibatan belajar siswa belum optimal; 3) Motivasi, perhatian dan minat belajar masih sangat minim; 4) Pengelolaan pembelajaran perlu dioptimalkan melalui penerapan metode eksperimen; 5) Prestasi belajar siswa masih belum memenuhi tingkat minimal 7,0 (70\%).

\section{Metode}

Penelitian ini merupakan penelitian kelas (PTK) maka rancangan penelitian ini sesuai dengan prosedur penelitian tindakan kelas yang dilakukan dalam suatu proses berdaur/ bersiklus, dimana setiap siklus terdiri dari: perencanaan, tindakan, observasi, dan refleksi. Hal ini sesuai dengan pendapat Kemmis S, dan M.C Tanggrat (1998), yang menyatakan bahwa PTK adalah siklus refleksi diri yang berbentuk spiritual dalam rangka melakukan proses perbaikan terhadap kondisi yang ada. Mencarikan solusi dalam memecahkan masalah yang dihadapi, dan dalam rangka menemukan cara-cara baru yang lebih baik dan lebih efektif untuk mencapai hasil yang lebih optimal. Berdasarkan analisis terhadap permasalahan yang ada, penelitian tindakan kelas ini direncanakan terdiri dari 2 (dua) siklus, dimana setiap siklus terdiri dari 4 (empat) fase, yaitu perencanaan tindakan, pelaksanaan tindakan, observasi tindakan, dan refleksi terhadap tindakan yang telah dilakukan pada setiap siklus. Namun demikian, keputusan untuk melanjutkan atau menghentikan penelitian pada akhir siklus tertentu, sepenuhnya tergantung pada hasil yang dicapai pada siklus terakhir. Bila hasil yang dicapai telah memenuhi kriteria keberhasilan yang telah ditetapkan, maka penelitian dihentikan dan bila belum mencapai hasil sesuai dengan yang diharapkan maka penelitian dilanjutkan ke siklus berikutnya.

Penelitian ini merupakan penelitian tindakan kelas yang dilakukan atau dilaksanakan dalam dua siklus yang masing-masing siklus terdiri dari 4 tahapan yaitu 1) Perencanaan, 2) Pelaksanaan, 3) Observasi/ Evaluasi, dan 4) Refleksi. Adapun kegiatan yang dilakukan pada setiap fase adalah sebagai berikut: 1) Fase Perencanaan, Berdasarkan refleksi awal terhadap permasalahan yang ingin ditanggulangi bahwa ternyata hasil belajar siswa mengenai materi "alat-alat transportasi" menunjukkan hasil belajar yang relatif rendah, sehubungan dengan hal tersebut, maka penelitian melakukan perencanaan penelitian yang meliputi (1) Mengadakan pertemuan dan minta izin kepada Kepala SD No. 3 Petak, (2) Penyusunan skenario pembelajaran termasuk mempersiapkan media yang diperlukan, dan (3) Membuat/ menyediakan instrumen berupa butir-butir soal yang diperlukan dalam mengetahui hasil belajar; 2) Fase Pelaksanaan Tindakan, Pelaksanaan tindakan dilakukan berupa pertemuan mengajar di kelas. Tindakan di kelas sesuai dengan skenario pembelajaran yang telah dirancang; 3) Fase Observasi, Observasi dilakukan dalam rangka pengumpulan data diperlukan untuk mengetahui kinerja siklus.Observasi dilakukan baik pada saat pembelajaran berlangsung maupun pada akhir pembelajaran.Selanjutnya pada akhir pembelajaran dilaksanakan penelitian dengan pemberian tes yang telah disusun; 4) Fase Refleksi, Refleksi adalah peninjauan terhadap kinerja siklus yang dilakukan setelah analisis data yang telah dikumpulkan. Analisis data ini berupa temuan siklus, dan temuan inilah digunakan sebagai bahan refleksi. Hasil refleksi berupa rekomendasi untuk melanjutkan atau menghentikan siklus penelitian.Data yang diperlukan dalam penelitian ini adalah data yang dapat digunakan untuk melihat prestasi belajar IPA.Untuk mendapatkan data tentang prestasi belajar siswa digunakan tes prestasi belajar dan nilai raport. Teknik analisis data yang digunakan dalam penelitian tindakan kelas ini adalah metode deskriptif, yaitu mendeskripsikan tentang jenis-jenis media belajar yang diberikan oleh guru kepada siswa. Sedangkan untuk manfaat media gambar dalam pengajaran terhadap peningkatan prestasi belajar siswa yang rendah dianalisis dengan menggunakan rumus berikut.

$$
\begin{aligned}
& \quad \frac{x-y}{y} x 100 \% \\
& \mathrm{~N}=\quad \text { (Wardani, dkk. 2001) } \\
& \text { Keterangan } \\
& \mathrm{N}=\text { Prosedur Peningkatan } \\
& \mathrm{X}=\text { Prestasi setelah diberikan tindakan } \\
& \mathrm{Y}=\text { Prestasi sebelum diberikan tindakan }
\end{aligned}
$$

\section{Hasil Dan Pembahasan}

Data yang dikumpulkan dianalisis secara deskriptif kuantitatif seperti menentukan modus, median dan mean (rata-rata). Data prestasi belajar diambil dari nilai tes siklus I dan siklus II.Sebelum 
siklus I dilaksanakan, dilakukan tes pra siklus untuk mengetahui prestasi belajar siswa sebelum dilaksanakan tindakan perbaikan.

Pada tes pra siklus diperoleh rata-rata nilai siswa sebesar 4,50 dengan 10 orang siswa yang berada di bawah standar KKM dengan nilai sebesar 40. Siswa yang ditindaklanjuti pada siklus I adalah 10 orang yang tidak memenuhi KKM pada tes pra siklus.Sementara siswa-siswa yang sudah memenuhi KKM tidak ditindaklanjut. Pelaksanaan kegiatan siklus I lebih menekankan pada prestasi belajar siswa dengan menggunakan metode eksperimen. Berikut ini adalah hasil evaluasi siswa pada siklus I.

Tabel 1 Hasil Evaluasi Siklus I

\begin{tabular}{clcc}
\hline No & \multirow{2}{*}{ NISN Siswa } & Pra Siklus & Nilai \\
\hline 1 & 9995410157 & 40 & Siklus I \\
2 & 999541146 & 40 & 50 \\
4 & 49985236976 & 40 & 60 \\
6 & 0004211902 & 40 & 60 \\
8 & 0004211903 & 40 & 50 \\
11 & 0004211907 & 40 & 60 \\
13 & 0004211898 & 40 & 60 \\
15 & 004211896 & 40 & 50 \\
18 & 9995410160 & 40 & 60 \\
19 & 9995410155 & 40 & 50 \\
& Jumlah & 40,00 & 60 \\
\hline
\end{tabular}

Berdasarkan data nilai pada siklus I tersebut, diperoleh rata-rata sebesar 5,60 dan 4 orang siswa yang belum mencapai KKM sebesar 5,8.

$$
\begin{aligned}
& \text { Keberhasilan secara klasikal }=\frac{\text { Jumlah siswa yang tuntas }}{\text { Jumlah seluruh siswa }} \times 100 \% \\
& =\frac{6}{10} \times 100 \% \\
& =60 \%
\end{aligned}
$$

Berdasarkan perhitungan tersebut, hasil penelitian pada siklus I ini belum berhasil karena ratarata nilai siswa yaitu sebesar 5,60 belum memenuhi standar $\geq 70$, keberhasilan siswa secara klasikal belum mencapai $70 \%$ dan secara individu masih ada 4 siswa yang belum mencapai 5,8. Berdasarkan hasil evaluasi pra siklus yang dilaksanakan terlihat 10 orang yang belum memenuhi KKM. Pada siklus I 10 orang siswa ini ditindaklanjuti. Diharapkan pada siklus I prestasi belajar 10 orang siswa ini dapat meningkat melalui mengoptimalkan penggunaan metode eksperimen. Hasil yang diperoleh pada siklus I sudah meningkat dibandingkan tes pra siklus. Namun demikian hasil ini belum memenuhi kriteria yaitu rata-rata kelas sebesar 5,60 belum mencapai kriteria $\geq 70$, secara individu masih ada 4 siswa yang belum mencapai nilai 5,8 dan keberhasilan secara klasikal belum mencapai 70\% yaitu hanya sebesar $60 \%$. Siswa yang ditindaklanjuti pada siklus II adalah 4 orang siswa yang belum memenuhi KKM pada siklus I. sementara siswa yang telah memenuhi KKM tidak ditindaklanjuti lagi. Hasil penelitian siklus I belum memenuhi kriteria yang diharapkan. Hal ini disebabkan adanya kendala pada siklus I yaitu: a) Masih ada siswa yang kebingungan dalam hal menarik kesimpulan dari eksperimen yang telah dilakukan. Namun hal ini dapat diatasi dengan memberikan bimbingan secara detail; b) Terdapat beberapa siswa yang berkemampuan kurang, tidak berani bertanya kepada anggota kelompok yang memiliki kemampuan lebih mengenai materi yang sulit; c) Beberapa siswa cenderung pasif saat mengerjakan tugas kelompok; d) Anggota kelompok masih homogen.

Berdasarkan kendala-kendala yang dihadapi pada siklus I, maka akan dilaksanakan tindak perbaikan pada siklus II dengan melaksanakan hal-hal berikut; a) Menyiapkan alata-alat dan fasilitas yang lengkap; b) Guru memberikan dorongan kepada siswa yang memiliki kemampuan kurang, agar mau bertanya dan siswa yang berkemampuan lebih agar bersedia membantu temannya; c) Guru memberikan pengertian kepada siswa bahwa keaktifan seluruh anggota kelompok sangat penting dalam menyelesaikan tugas; d) Anggota kelompok dibentuk secara heterogen. Pada siklus II, guru memperhatikan kendala-kendala yang dihadapi dalam siklus I dan menerapkan tindakan yang telah disebutkan di atas untuk mengatasi kendala tersebut agar tidak terjadi lagi pada siklus II.

Tabel 2 Hasil Evaluasi Siklus II

No NISN Siswa Nilai




\begin{tabular}{clcc} 
& & Siklus I & Siklus II \\
\hline 1 & 9995410157 & 50 & 70 \\
2 & 999541146 & 60 & - \\
4 & 49985236976 & 60 & - \\
6 & 0004211902 & 50 & 70 \\
8 & 0004211903 & 60 & - \\
11 & 0004211907 & 60 & - \\
13 & 0004211898 & 50 & - \\
15 & 004211896 & 60 & 70 \\
18 & 9995410160 & 50 & - \\
19 & 9995410155 & 60 & 71,25 \\
\hline
\end{tabular}

Berdasarkan data nilai siswa pada siklus II tersebut, diperoleh rata-rata / mean sebesar 71,25.

$$
\begin{aligned}
\text { Keberhasilan secara klasikal } & =\frac{\text { Jumlah siswa yang tuntas }}{\text { Jumlah seluruh siswa }} \text {. } \\
& =\frac{4}{4} \times 100 \% \\
& =100 \%
\end{aligned}
$$

Berdasarkan perhitungan tersebut, hasil penelitian pada siklus II ini dapat dikatakan telah berhasil karena rata-rata nilai siswa sudah memenuhi standar yaitu $\geq 70$.Keberhasilan.Berdasarkan hasil evaluasi yang dilaksanakan pada siklus II, diperoleh rata-rata prestasi siswa 71,25. Rata-rata nilai naik sebesar 65,65 dari rata-rata pada siklus I. Rata-rata prestasi belajar siswa pada siklus II ini telah memenuhi kriteria yang diharapkan yaitu $\geq 70$ selain itu, $100 \%$ siswa telah memperoleh nilai $\geq 58$ dan ketuntasan secara klasikal mencapai angka $100 \%$. Hal ini berarti penelitian ini dapat dikatakan telah berhasil, karena telah memenuhi semua kriteria yang ditetapkan dan mampu meningkatkan prestasi belajar siswa.Siklus II ini merupakan klimaks dari penerapan siklus-siklus pembelajaran dalam mata pelajaran Ilmu Pengetahuan Alam terutama dalam penanaman konsep-konsep dan fakta-fakta ilmiah.

Dengan perbaikan yang telah dilakukan, prestasi belajar IPA siswa pada siklus II telah memenuhi kriteria yang diharapkan yaitu $100 \%$ siswa memperoleh nilai $\geq 58$ rata-rata kelas $\geq 70$ dan ketuntasan secara klasikal mencapai angka 100\%. Hal ini berarti penguasaan siswa terhadap materi yang diberikan dalam pembelajaran sudah baik.Untuk itu penelitian ini sudah cukup dilaksanakan sampai siklus II. Segala proses kegiatan, baik dari perencanaan tindakan maupun pelaksanaan tindakan yang dilakukan pada siklus II. Hasil refleksi siklus II ini menunjukkan bahwa penerapan metode eksperimen berbantuan LKS dapat membuat siswa lebih aktif dan membangkitkan rasa ingin tahu, dapat mengembangkan sikap kritis dan ilmiah yang sumber medianya maupun sumber belajarnya berasal dari lingkungan dan siswa termotivasi untuk belajar dan berubah ke arah yang lebih baik.

Dengan demikian, secara umum penelitian ini dapat dikatakan berhasil, sebab hasil penelitian telah memenuhi kriteria yang telah diterapkan dengan kata lain optimalisasi penggunaan metode eksperimen dalam pembelajaran IPA untuk meningkatkan prestasi belajar siswa kelas IV SD No. 3 Petak Gianyar Tahun Pelajaran 2010/2011.

\section{Simpulan Dan Saran}

Berdasarkan analisis data yang disajikan dalam bab IV, maka dapat ditarik kesimpulan sebagai berikut: 1) Bahwa dalam penggunaan metode eksperimen dapat meningkatkan prestasi belajar siswa; 2) optimalisasi penggunaan metode eksperimen dalam pembelajaran IPA memerlukan waktu yang cukup lama. Adapun saran-saran yang dapat disampaikan sehubungan dengan hasil penelitian ini adalah: 1) Bagi guru-guru SD Negeri 3 Petak diharapkan menggunakan metode eksperimen secara optimal; 2) Bagi pembaca yang berminat dan para guru hendaknya selalu meningkatkan kreatifitasnya melakukan eksperimen dalam pembelajaran mata pelajaran IPA.

\section{Daftar Pustaka}

Ali, Muhammad. (1993). Media Pengajaran.Bandung : Tiga Serangkai.

Aristo Rahadi. (2003). Media Pembelajaran. Departemen Pendidikan Nasional Direktorat Jendral Pendidikan Dasar dan Menengah, Direktorat Tenaga Kependidikan. Jakarta. 
Dinas Pendidikan Nasional, (1994). Kurikulum Pendidikan Dasar Kelas VI.

Departemen Pendidikan Nasional. (2003). Buku IPA Guru Kelas VI. Jelajah IPA. Jakarta : Yudhistira.

Dinas Pendidikan Nasional. (2006). Kurikulum Tingkat Satuan Pendidikan Sekolah Dasar.Jakarta.

Eka Purjianto, dkk. (2007). Langkah Tepat Menuju Olimpiade Sains Sekolah Dasar. Jakarta : Azka Mulia Media.

H. Panut, dkk. (2005). Dunia Sains.Jakarta : Yudhistira.

Safari, dkk. (2004). Evaluasi Pembelajaran.Departemen Pendidikan Nasional Direktorat Jenderal Pendidikan Dasar dan Menengah, Direktorat Tenaga Kependidikan. Jakarta.

SD Negeri 3 Petak. Kurikulum Tingkat Satuan Pendidikan Sekolah Dasar. Gianyar.

Tabrani Rusyan. A. (1993). Proses Belajar Mengajar Yang Efektif Tingkat Pendidikan Dasar.Jakarta : Bina Budaya.

Winarno Udin S, dkk. (2001). Strategi Belajar Mengajar. Jakarta : Pusat Penerbitan Universitas terbuka. 